УДК 340.12:(007:342.5/6)

DOI https: / / doi.org/10.32837/yuv.v0i4.937

\title{
I. Антошина,
}

кандидат юридичних наук,

доцент кафедри загальнотеоретичної юриспруденціі

Національного університету «Одеська юридична академія»

\section{ІНФОРМАЦІНА ВЛАДА: ЗМІСТ І ЗНАЧИМІСТЬ У СУЧАСНИХ УМОВАХ}

В сучасних умовах інформаційне суспільство створює інформаційний простір, який являє собою соціальне середовище, у якому здійснюється виробництво, збирання, зберігання, поширення i використання інформаціi. Інформаційний простір використовується як інструментарій для вирішення соціальних, політичних економічних чи військових завдань, де головну роль відіграють саме засоби масової інформації. Однак, варто зазначити, що саме відповідальність за якість інформаційного простору України лежить на кожному його учаснику - i на політиках, і на журналістах, і на суспільстві як споживачеві інформаційного продукту. Так, сьогодні однією з проблем функціонування інформаційної влади $€$ не сформованість єдиного українського інформаційного простору. Інформаційний простір, де панує інформація, на наш погляд, не має чітко встановлених кордонів, що, в свою чергу,_робить інформацію та їі вплив на широкі маси населення необмеженим.

У науковій літературі виділяють економічну, ідеологічну, політичну, державну, духовну та інші різновиди влади. Виділяється також інформаційна влада, яка останнім часом стало предметом пильної уваги наукових досліджень. Серед зарубіжних дослідників, що займаються даною проблематикою, особливо виділяються С. Белл-Рокич, M. Дефлер, Т. Беннет, Э. Вартем, Дж. Лал, Г. Лассвел, В. Липпман, Э. Ноель-Нойман, Э. Тоффлер, Е. Хилл и др. Що стосується вітчизняних дослід- ників інформаційної влади, можна виділити: А. Гриценко, В. Иванова, M. Каращука, М. Костенко, Б. Кормича, А. Ручки та ін...

Метою даної статті $€$ визначення сутності інформаційної влади, ї̈ взаємодії з державною владою, так як, сьогодні, інформаційна влада перетворюється в потужний фактор суспільного розвитку.

Що стосується інформаційної влади, то більшість вчених під інформаційною владою, розуміють здатність власників інформації шляхом отримання, селекції, тлумачення, компонування та поширення інформації впливати на формування суспільної свідомості, спонукати суб'єктів політики і економіки до дій в заданому напрямку.

Інформаційна влада інституціоналізується через спеціалізовані структури для відкритої, публічної передачі будь-якої інформації будь-яким особам за допомогою спеціального технічного інструментарію. До них відносяться друкована, аудіовізуальна, електронна преса, кіно-, відео-, аудіо носії інформаціi, супутникові, кабельні, комп'ютерні мережі - все, що може накопичувати і передавати важливу для суспільного життя інформацію [1].

Всеосяжна інформатизація суспільства, широке впровадження нових інформаційних технологій (телебачення, комп'ютерних мереж, аудіота відеосистем, інтернет-телебачення, соціальних мереж) актуалізували дискусії про інформаційну владу. Тут можемо виділити кілька дефініцій 


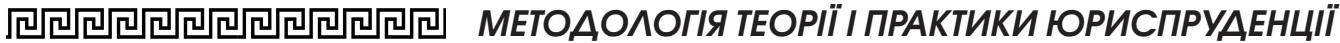

поняття інформаційної влади. Інформаційна влада - по-перше, це влада якоїсь інформації (ідей), прийнятої до реалізації, а по-друге, влада людей, які втілюють інформацію (ідеї) в життя [2].

Суть інформаційної влади зводиться до здатності поширення за допомогою засобів масової інформації та міжособистісного спілкування певних ідей. Вона спрямована на те, що люди починали адекватно сприймати інформацію, що надходить та яка, в свою чергу починає формувати алгоритм їх поведінки. На думку $M$. Каращука, інформаційна влада - це системно-функціональна взаємодія, особливого роду зв'язок, який забезпечує здатність суб'єктів за допомогою цілеспрямованого поширення інформації реалізовувати свої цілі [3, с. 324-335].

У сучасному світі, як зазначає Ю. Турченко, де інформація виступає як основна цінність, питання про інформаційну влади в соціально-політичній структурі суспільства $€$ наріжним як для теоретиків - політологів, соціологів, правознавців, психологів, так і для практиків - політиків, журналістів [ 4, с. 115].

Інформаційна влада формується в рамках громадянського суспільства, що представляє собою систему самостійних i незалежних від держави суспільних інструментів та відносин, які покликані забезпечити необхідні умови для реалізації прав і свобод, а також приватних інтересів і потреб окремих людей і їх колективів, для насиченого соціального, культурного та духовного життя.

Глобальний розвиток інформаційного суспільства сприяе можливості інтенсивного інформаційного обміну, який відбувається в інформаційній взаємодії зацікавлених суб'єктів. Саме інформація виступає найважливішим елементом, наповненням комунікації та опосередковує усі комунікативні процеси. Комунікація скріплює будь - яке суспільство та сприяє його розвитку, виступає не тільки умовою та формою існування соціуму, але і права. А. Поля- ков та Е.Тимошина визначають інформаційну природу права як оснований на соціально визнаних та загальнообов'язкових нормах комунікативний порядок відносин, учасники якого взаємодіють шляхом реалізації своїх прав та обов'язків [5, с. 331]

Сферою правового регулювання інформаційного суспільства виступає соціальний простір, який необхідно впорядкувати за допомогою правових засобів на основі використання досягнень інформаційно-технологічного прогресу. Право може впливати на інформаційну сферу за допомогою правового регулювання, також правового впливу. Об'єктом правового регулювання інформаційних відносин виступає правова реальність, пов'язана 3 формуванням, функціонуванням та розвитком інформаційного суспільства. Предметом правового регулювання інформаційних відносин $€$ сукупність суспільних відносин, пов'язаних з використанням різних інформаційно-комунікаційних технологій 3 метою створення, накопичення інформації та знань, а також розвитку і реалізації свого потенціалу.

Актуальним є взаємодія інформаційної влади з державною владою. Державна влада передбачає наявність суб'єкта влади, того, хто здійснює владні відносини і об'єкта владних відносин, тобто той, щодо кого вона застосовується. Не менш важливими виступають джерела і засоби, за допомогою яких здійснюють владу; мета, заради якої владу застосовують. Суб'єктами державної влади перш за все виступають інститути держави. Що стосується суб'єктів інформаційної влади в сучасному суспільстві, то ними виступають такі інститути як 3MI, інформаційні та рекламні агентства, наукові та науково - освітні установи. Найбільш масове і вагомий вплив мають Інтернет, 3MI (аудіовізуальні, телебачення, радіо), де Інтернет виступає головним творчим полем діяльності сучасного суспільства.

При розгляді питань щодо функціонування державної влади, то вона 


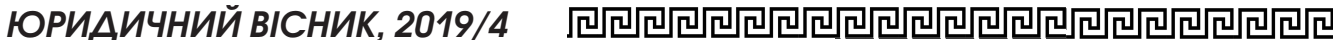

$€$ обмеженою, тоді як на відміну від державної влади інформаційна влада, на шляху свого впливу на свідомість і волю людей, є необмеженою. Державна влади має адресний характер, спрямований на все населення або на певні верстви, або на обличчя, які безпосередньо беруть участь в конкретній справі. Що стосується інформаційної влади, то можна спостерігати, що іï волевиявлення не має конкретних адресатів. Масштаб і активність впливу залежить від переконливості, доказовості, правильної подачі, привабливості інформації.

3 метою підкорювати одного суб'єкта іншому або одних суб'єктів іншим державна влада може використовувати як метод примусу, так і метод переконання для виконання владних вимог. Що стосується інформаційної влади, то вона не має здатність і можливість насильно примушувати до вчинення будь-які діі. Інформаційна влада може задіяти метод переконання.

Влада $€$ універсальним механізмом інтеграції та впорядкування поведінки людей. В першу чергу вона представлена державою, іï ресурсами [6]. Ресурси державної влади складаються з потенційних засобів, які можуть бути задіяні при реалізації функцій держави. Головним ресурсом інформаційної влади виступають засоби масової інформації (3MI),які мають досить потужні можливості впливу на їх свідомість та поведінку, все це дає підстави розглядати 3MI, саме як потужний інструмент інформаційної влади. Сутність інформаційної влади полягає в корекції мислення або впровадженні нових смислів в старі ідеї та їх популяризація.

Інформаційна влада в сучасних умовах відіграє визначальну роль в житті сучасного суспільства. Під впливом інформаційної влади змінюються більшість політико-правових інститутів, політичні відносини, форми політичного та інформаційного впливу на суспільні відносини і суспільну свідомість.

Інформаційна влада чинить широкий вплив на формування поведінки особистості і суспільства в цілому, вміло маніпулює свідомістю людей, за допомогою цілеспрямованого впливу інформації або блокування певних відомостей, пропагандистських і агітаційних матеріалів, інформації, які і не сприймаються нами, як примус.

Що стосується державної влади, то вона може домагатися своїх цілей різними засобами, в тому числі ідеологічним впливом, переконанням, економічним стимулюванням і іншими способами. Але тільки вона володіє монополією на примус за допомогою спеціального апарату по відношенню до всіх членів суспільства. Внаслідок цього формами прояву влади є панування, керівництво, управління, організація, контроль.

Формування інформаційної влади безпосередньо пов'язане зі становленням інформаційного суспільства, в якому інформація стає головним економічним ресурсом, а інформаційний сектор виходить на перше місце за темпами зростання; основною формою власності стає інтелектуальна власність, важливого значення набуває людський капітал; інформація стає предметом масового споживання (з'являються нові критерії оцінки рівня розвитку суспільства - кількість комп'ютерів, кількість підключень до Інтернету, кількість мобільних і стаціонарних телефонів, та ін.), формуються нові правові засади функціонування інформаційного суспільства; формується єдина інтегрована інформаційна система на основі технологічної конвергенції (злиття телекомунікацій, комп'ютерно-електронної, аудіовізуальної техніки), створюються єдині національні інформаційні системи [7, с. 16-17].

Перехід від індустріального до інформаційного суспільства $€$ нагальною реальністю нашого часу і зачіпає всі держави, де Україна не є винятком. Перехід до інформаційної цивілізації перетворює інформаційний ресурс на стратегічний фактор будь-якої країни [8, с. 3].

Інформаційне суспільство створює інформаційний простір, який являє 


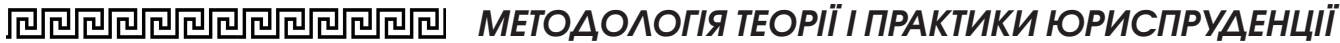

собою соціальне середовище, в якому здійснюється виробництво, збір, зберігання, поширення і використання інформаціі. І Інформаційний простір використовується як інструментарій для вирішення соціальних, політичних економічних або військових завдань, де головну роль відіграють саме засоби масової інформації. Однак, необхідно відзначити, що саме відповідальність за якість інформаційного простору лежить на кожному з його учасників - і на політиках, і на журналістах, і на суспільстві як споживачеві інформаційного продукту.

У сучасних умовах однією з важливих проблем функціонування інформаційної влади є формування єдиного інформаційного простору. Інформаційний простір не має чітко встановлених меж, що, в свою чергу, робить інформацію і іï вплив на широкі маси населення необмеженим.

Необхідно акцентувати увагу на тому, що в останне десятиліття спостерігається стрімке зростання політичного впливу інформаційної влади, ii значення, роль у житті суспільства. Свобода слова та інформації на основі верховенства права i поваги прав людини є основними постулатами побудов громадянського суспільства, утвердження справжньої демократії. Тому, без сумніву межі існування інформаційної влади повинні бути узгоджені з правами і свободами людини.

Існування державної влади сьогодні неможливо без використання інформаційних технологій наочно демонструє нам глобальне зростання інформаційного обміну, значимості інформації в суспільстві. Неможливо не погодитись 3 тим що інформація нині виступає першоосновою світу: «У суспільстві циркулює велика кількість інформації, яка заволоділа свідомістю, поведінкою людей; вона скрізь і всюди, всередині нас, між нами та навколо нас» [9, с. 14].

Основами правового регулювання інформаційних відносин в Україні є Конституція України та Закон Украіни «Про основні засади розвитку інформаційного суспільства в Україні на 2007 - 2015 роки» [10], згідно 3 якими держава створює умови для розвитку інформаційного суспільства в Україні. Було прийнято ряд спеціально нормативно-правових актів, які спрямовані на регулювання оптимального використання інформаційних технологій. Створення спеціальних державних структурних підрозділів, які займаються впровадженням інформаційної політики в життя населення і виконанням державних програм.

Кабінет міністрів України 20 вересня 2017 р. своїм розпорядженням «Про схвалення Концепції розвитку електронного урядування в Україні» акцентує увагу на тому, що у рамках реалізації угоди про асоціацію між Україною, з однієі сторони, та Європейськім Союзом, Європейськім співтовариством 3 атомної енергії і їніми державами-членами, з іншої сторони , Україна має забезпечити комплексний розвиток електронного урядування відповідно до європейських вимог.

Державне управління в Україні потребує модернізації шляхом реінжинірингу існуючих та проектування оновлених адміністративних процесів в органах влади, оптимізованих 3 використанням сучасних інформаційно-комунікаційних технологій, спрямованих на електронну взаємодію та спільну роботу, відкритість та прозорість для громадян.

Запровадження автоматизованого обміну даними між інформаційно-телекомунікаційними системами органів влади дасть змогу забезпечити підвищення ефективності роботи органів влади шляхом скорочення часу отримання необхідних даних, покращення якості та актуальності опрацьованих даних, ліквідації багаторазового збору та дублювання даних в різних інформаційних системах, покращення доступності інформаційних ресурсів та їх систематизацію[11].

Закон України «Про основні засади забезпечення кібербезпеки України" визначає основні правові та органі- 


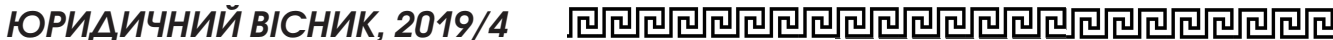

заційні засади забезпечення захисту життєва важливих інтересів людини і громадянина, суспільства і держави, національних інтересів України в кіберпросторі, основні цілі, напрямки та принципи державної політики, зокрема в сфері кібербезпеки. Відставання правового регулювання суспільних відносин в інформаційній сфері від появи нових засобів обробки інформації і комунікації не дає можливість державі швидко і чітко відповісти новим викликам i загрозам, що виникли в даній сфері [12].

Зростання значущості інформації в житті кожної людини отримує своє відображення в правах i свободах людини і громадянина. Право громадян України на інформацію набуває важливого значення, відповідно Конституція України закріпила право людини на свободу інформації. Так, ст. 34 Конституції України гарантує кожному громадянину право вільно збирати, зберігати, використовувати та поширювати інформацію [13].

Закон України «Про інформацію», державну інформаційну політику визначає як сукупність основних напрямів і способів діяльності держави по одержанню, використанню, поширенню та зберіганню інформаціі. Закон закріплює гарантованість права на інформацію; відкритість, доступність інформації, свободу обміну інформацією; достовірність і повноту інформації; свободу вираження поглядів і переконань; правомірність одержання, використання, поширення, зберігання та захисту інформації і захищеність особи від втручання в іï особисте та сімейне життя [14].

Таким чином, право на доступ до інформації стає одним 3 невід'ємних прав людини і громадянина. Пріоритетним завданням української держави $€$ забезпечення свободи слова, свободи інформації, право на вираження думки i позиції громадянина, право на отримання і поширення достовірної інформації без перешкод. Найважливіше значення для подальшого розвитку українського суспільства полягає у взаємодії державної влади 3 інформаційною владою. В сучасних умовах інформаційна влада визначальним чином впливає на різні сфери суспільного розвитку, що трансформує багато політичних та державних інститутів. Ефективність державної влади багато в чому залежить від всебічного регулювання інформаційних відносин, що визначає характер іiі взаємодіі з інформаційною владою.

Формування інформаційної влади безпосередньо пов'язане зі становленням інформаційного суспільства, в якому інформація стае головним економічним ресурсом, а інформаизйний сектор виходить на перше місие за темпами зростання. Iнтелектуальна власність стає основною формою власності, важливим стає людський капітал; інформація стає предметом масового споживання, формуються нові правові основи функціонування інформаційного суспільства. Tепер свобода слова та інформациї на засадах верховенства права та повага прав людини - ие основні постулати створення громадянського суспільства, заява про справжню демократію. Тому межі існування інформаційної влади мають бути узгоджені з правами та свободами людини. Отже, право на доступ до інформації стає одним з невід'ємних прав людини $i$ громадянина. Пріоритетним завданням Украйнської держави є забезпечення свободи слова, свободи інформаціі, права на висловлення думок та позиизї громадянина, права на отримання та поширення достовірної інформаиії без перешкод.

Суть інформаційної влади зводиться до здатності поширення за допомогою засобів масової інформаияї та міжособистісного спілкування певних ідей. Право на доступ до інформаиї стає одним з невід'ємних прав людини $і$ громадянина. Пріоритетним завданням украйнської дер- 


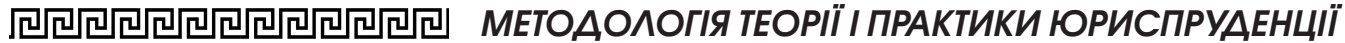

жави є забезпечення свободи слова, свободи інформації, право на вираження думки $і$ позиції громадянина, право на отримання $i$ поширення достовірної інформації без перешкод. Найважливіше значення для подальшого розвитку українського суспільства полягає у взаємодії державної влади з інформаційною владою. $B$ сучасних умовах інформаційна влада визначальним чином впливае на різні сфери суспільного розвитку, щз трансформуе багато політичних та державних інститутів. Ефективність державної влади багато в чому залежить від всебічного регулювання інформаційних відносин, щзо визначає характер ї взаємодіі з інформаційною владою.

Ключові слова: інформація, інформаційне суспільство, інформаційний простір, інформаційна влада, державна влада, ресурси влади, право на доступ до інформації, право на інформацію.

\section{Antoshyna I. INFORMATION POWER: CONTENT AND SIGNIFICANCE IN THE CURRENT CONDITIONS}

In modern conditions the information power directly bind with formation of an information society, in which information becomes the main economic resource, and the information sector comes out on the top on rate of growth. The intellectual property becomes the main form of ownership, a human capital becomes the important; an information becomes a subject of mass consumption, the new legal bases of functioning of an information society are formed. Now, freedom of speech and information on the basis of the rule of law and the respect of human rights are the main postulates of the creation of a civil society, the statement of a real democracy. Therefore, the limits of the existence of the information power have to be agreed with the rights and the freedoms of a person. So, the right for access to information becomes one of inalienable rights of a human and a citizen. A priority task of the Ukrainian state is the ensuring the freedom of speech, the freedom of an information, the right for expression of opinion and the citizen's position, the right for the receipt and the dissemination of the reliable information without obstacles.

The essence of information power comes down to the ability to disseminate through the media and the interpersonal communication of certain ideas. The right to access information becomes one of the inalienable human and citizen rights. The priority task of the Ukrainian state is to ensure freedom of speech, freedom of information, the right to express the opinion and position of a citizen, the right to receive and impart reliable information without hindrance. The most important for the further development of Ukrainian society is the interaction of the state power with the information power. In modern conditions information power has a decisive influence on the various spheres of social development, which transforms many political and state institutions. The effectiveness of state power largely depends on the comprehensive regulation of information relations, which determines the nature of its interaction with the information power.

Key words: information, information society, information space, information power, state power, power resources. information, information society, information space, information power, state power, state resources, right of access to information, right to information.

\section{Література}

1. Бебик В. М. Політологія для політика і громадянина: [Монографія]. - К.: МАУП, 2003.: [Электронный ресурс]. Режим docmyna:https: / / wшш.politics.ellib. org.ua / pages-3665.html

2. Ржевська Н. Ф., Політична влада та інформація, місце інформаційної влади у інформаційному суспільстві. / Електронний pесурсl. - Режим docmyny : jrnl.nau. edu.ua/index.php/IMV/article/view/2950

3. Каращук М. Інформаційна влада: сут- 


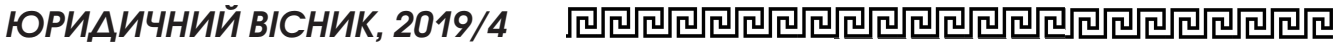

ність та особливості впливу / М. Г. Каращук / / Наукові записки Iнституту політичних $і$ етнонаціональнихдослідженьім. I. Ф. Kypaca. - 2012. - Bun. 3. - C. 324-335.

4. Турченко Ю. ЗМІ як впливовий чинник реалізації політичного процесу // Ю.Турченко / / науковий співробітник Військового інституту Київського національного університету ім. Т. Шевченка // Громадське суспільство / / Політичний менеджмент № 4 2009.- С. 115-118.

5. Поляков А.В., Тимошина Е.В. Общая теория права / / А.В. Поляков, Е.В. Тимошина / Учебник. СПб, 2005. - 472 с.

6. Общетеоретическая юриспруденици : учебный курс : Учебник / Под. ред. Ю. Н. Оборотова. - О. :Юрид. л-ра, 2011. $627 \mathrm{c}$.

7. Чугунов А.В. Развитие информаизионного общества: теории, конщепции и программы /учебное пособие] / A.В. Чугунов. - СПб.: Ф-т филологии и искусств СПбГУ, 2007. - 98 с.

8. Правове забезпечення інформаційної діяльності в Україні / за заг. ред. Ю. С. Шемшученка, I. С.Чижа. - К. : Юрид. думка, 2006. - - $411 \mathrm{c}$.
9. Юзвишин И. И. Информащиология / И. И. Юзвишин. - М. : Информациология, 1996. -220 c.

10. «Про Основні засади розвитку інформаційного суспільства в Україні на 2007-2015 роки» Закон України від 09.01.2007 № 537-V https://zakon.rada. gov.ua/laws / show/537-16

11. Про схвалення Концепиіï розвитку електронного урядування в Україні Розпорядження кабінету міністрів України від 20 вересня 2017 р. № 649-р /Електронний pecypcl. - Pежuм docmyny: https:// zakon2.rada.gov.ua/laws / show /649-2017-p

12. Закон України «Про основні засади забезпечення кібербезпеки України» от 05.10.2017 № 2163-VIII /Електронний pecypcl. - Pежuм docmyny : http://search. ligazakon.ua/l_doc2.nsf/link1/T172163.html

13. Конституція України : прийнята Верховною Радою України 28 червня 1996 р. / / Відомості Верховної Ради України. - 1996. - № 30. - Ст. 147.

14. «Про інформацію» Закон України вї 13.11.1992, № 48, cm.650/Електронний pecypcl. - Pежuм docmyny : https://zakon. rada.gov.ua/laws/show/2657-12/ed20110106 